\title{
Multiple lactate dehydrogenase activities of the rumen bacterium Selenomonas ruminantium
}

\author{
Martin Gilmour, ${ }^{1}$ Harry J. Flint ${ }^{2}$ and Wilfrid J. Mitchell ${ }^{1}$ \\ Author for correspondence: Wilfrid J. Mitchell. Tel: +44314513459. Fax: +44314513009. \\ e-mail: BBSWJM@CLUST.HW.AC.UK
}

1 Department of Biological Sciences, Heriot-Watt University, Riccarton, Edinburgh EH14 4AS, UK

2 Rowett Research Institute, Bücksburn, Aberdeen AB2 9SB, UK

\begin{abstract}
The lactate utilizing strain of Selenomonas ruminantium 5934e was found to contain three lactate dehydrogenase (LDH) activities in sonicated cell extracts. One activity, an NAD dependent L-LDH (L-nLDH) was measured at 15-fold greater levels in extracts of cells grown to mid-exponential phase on glucose compared to cells grown to the equivalent growth stage on DL-lactate. A second nLDH activity specific for D-lactate (D-nLDH) was detected at similar levels in both lactate-grown cell extracts and glucose-grown cell extracts. The third activity, an NAD independent DLDH (D-iLDH) was very low in cells grown on glucose but was induced more than 10-fold when DL-lactate was used as the carbon source. The three LDH activities could be separated by gel filtration. Recovery of the activities was low due to the apparent instability of the enzymes at $4{ }^{\circ} \mathrm{C}$, which was most pronounced in the case of the D-iLDH. A $K_{m}$ for lactate of $0.5 \mathrm{mM}$ was estimated for the D-iLDH and this was considerably lower than the values of $45 \mathrm{mM}$ and $70 \mathrm{mM}$ measured for L-nLDH and D-nLDH respectively. It is proposed that the D-iLDH may be largely responsible for the formation of pyruvate in lactate-grown cells of 5 . ruminantium strain 5934e. Three other lactate utilizing strains of S. ruminantium, HD4, 5521C1 and JW13 exhibited a similar profile of LDH activities to strain 5934e when grown on glucose and DL-lactate.
\end{abstract}

Keywords: Selenomonas ruminantium, lactate dehydrogenases, rumen, anaerobe

\section{INTRODUCTION}

Selenomonas ruminantium is an abundant member of the rumen community that utilizes a wide range of soluble substrates for growth (Hungate, 1966) including glucose which is metabolized mainly to lactate, propionate, acetate and $\mathrm{CO}_{2}$ (Bryant, 1956). Furthermore, hydrogen can be consumed by $S$. ruminantium (Henderson, 1980) and can be produced in co-cultures with methanogenic bacteria (Scheifinger et al., 1975b). Previous work concerning the metabolism of $S$. ruminantium has concentrated on glucose catabolism and the regulation of pathways leading to lactate, propionate and acetate, and from such studies most of the enzymes responsible for production of these acids have been demonstrated (Melville et al., 1988a). Approximately $50 \%$ of isolated strains can also ferment

Abbreviations: APAD, 3-acetylpyridine adenine dinucleotide; DCPIP, 2,6dichlorophenol indophenol; $L D H$, lactate dehydrogenase; $n L D H, N A D-$ dependent $L D H$; $i L D H, N A D$-independent $L D H$; PMS, phenazine methosulphate. lactate (Flint \& Bisset, 1990) producing propionate, acetate and $\mathrm{CO}_{2}$. Little is known about the enzymes involved although the production of propionate from lactate has been shown to proceed via the 'succinate' pathway in studies using DL- $\left[2-{ }^{14} \mathrm{C}\right]$ lactate (Paynter \& Elsden, 1970). Of the other major lactate utilizing bacteria in the rumen, Veillonella alcalescens also produces propionate via the 'succinate' pathway (Johns, 1951), while Megasphaera elsdenii utilizes the 'acrylate' pathway (Baldwin et al., 1965).

During rapid growth of $S$. ruminantium on glucose, lactate is the major product of fermentation, while at lower growth rates acetate and propionate become the main products (Hishinuma et al., 1968; Scheifinger et al., 1975a; Melville et al., 1987). This difference appears to be due, at least in part, to homotropic activation of an NADdependent lactate dehydrogenase (nLDH) by its substrate, pyruvate (Wallace, 1978) and a higher $V_{\max }$ of the $\mathrm{nLDH}$ at higher growth rates may also be important (Melville $e t$ al., 1988b). 
A recent study on the electrophoretic mobility of enzymes in 36 S. ruminantium strains detected four mobility variants of nLDH (Flint \& Bisset, 1990), hinting at considerable genetic diversity among strains and the possibility of the existence of different LDH activities with different functions in the cell. An NAD-dependent LDH specific for L-lactate ( $\mathrm{L}-\mathrm{nLDH}$ ) has been detected in some strains (Joyner \& Baldwin, 1966; Scheifinger et al., 1975a; Melville et al., 1987, 1988a), whereas in WPL 151/1 the major $\mathrm{LDH}$ was NAD-dependent but specific for $\mathrm{D}^{-}$ lactate (D-nLDH). In other bacteria, nLDH enzymes appear to be involved in lactate formation from pyruvate, rather than lactate oxidation in vivo (Garvie, 1980). The conversion of lactate to pyruvate is associated with a different, NAD-independent lactate dehydrogenase (iLDH). iLDH may be membrane-bound and linked to electron transport (Kemp, 1972; Kohn \& Kaback, 1973), although in some bacteria which can grow on lactate soluble iLDHs have been reported (Molinari \& Lara, 1960; Wittenberger \& Haaf, 1966; Garvie, 1980). Among rumen bacteria, $M$. elsdenii possesses a constitutive DiLDH involved in lactate oxidation (Brockman \& Wood, 1975; Hino \& Kuroda, 1993), and the lactate fermenter Propionibacterium acnes exhibits iLDH activity (Counotte $e t$ al., 1980); on the other hand, the lactate producing strains Peptostreptococcus productus and Actinomyces viscosus, which do not ferment lactate, possess nLDH activity only (Counotte et al., 1980).

Little work has been done to determine whether a specific $\mathrm{LDH}$ activity is responsible for lactate oxidation in $S$. ruminantium. The fact that $\mathrm{L}-\mathrm{nLDH}$ has a far greater affinity for pyruvate than for lactate (Scheifinger et al., 1975a; Melville et al., 1988a) suggested that another enzyme would be responsible for lactate utilization. The purpose of this study was to investigate in detail the LDH activities present in $S$. ruminantium when utilizing lactate as compared to glucose as an energy source in an effort to establish the mechanism of lactate assimilation. The lactate utilizing strain S. ruminantium 5934e (Flint \& Bisset, 1990) was used because in our laboratory this strain grows much more efficiently on lactate in batch culture than the commonly studied strain HD4. The results show the existence of at least three distinct $\mathrm{LDH}$ activities in $S$. ruminantium $5934 \mathrm{e}$ which differ in their cofactor requirements, substrate affinities, stabilities and relative activities in lactate and glucose grown cells.

\section{METHODS}

Organisms. Selenomonas ruminantium 5934e, 5521C1, JW13 and FB322 were isolated from rumen fluid at the Rowett Research Institute (Wallace \& Brammall, 1985; Flint et al., 1988; Flint \& Bisset, 1990). Strain HD4 was originally isolated by Bryant (1956), strain D by John et al. (1974), and strain GA192 by Bryant (1984).

Anaerobic media and culture conditions. Anaerobic methods followed those of Bryant (1972). Cultures were maintained in basal M2 medium $+0 \cdot 2 \%$ (w/v) glucose, starch and cellobiose. This medium was similar to medium 2 of Hobson (1969) but with $30 \mathrm{ml}$ clarified rumen fluid and $0 \cdot 1 \mathrm{~g}$ cysteine. $\mathrm{HCl}$ added per $100 \mathrm{ml}$ medium. Stock cultures were stored at $-20^{\circ} \mathrm{C}$ on this medium containing $0 \cdot 75 \%$ agar. Basal M2 refers to the above medium with no added energy source. Basal M2 was supplemented with $0.5 \%(\mathrm{w} / \mathrm{v})$ glucose or $2 \%$ DL-lactate for the growth of cells in certain experiments (see Results). Smedium was identical to basal M2 except with no rumen fluid and $0.03 \mathrm{ml} \mathrm{n}$-valerate added per $100 \mathrm{ml}$.

D-medium contained (per $100 \mathrm{ml}$ final volume): BactoCasitone, $1 \mathrm{~g}$; mineral solution (a) (Hobson, 1969), $15 \mathrm{ml}$; mineral solution (b) (Hobson, 1969) lacking $\left(\mathrm{NH}_{4}\right)_{2} \mathrm{SO}_{4}, 15 \mathrm{ml}$; trace metals solution (Clark \& Holms, 1976), $0.5 \mathrm{ml}$; ammonium chloride, $0.1 \mathrm{~g} ; 0.1 \%(\mathrm{w} / \mathrm{v})$ resazurin, $0.1 \mathrm{ml} ; \mathrm{NaHCO}_{3}, 0.4 \mathrm{~g}$; haemin, $0.001 \mathrm{~g}$; L-methionine, $0.0045 \mathrm{~g}$; volatile fatty acid solution (Caldwell \& Bryant, 1966), $0.31 \mathrm{ml}$; cysteine. $\mathrm{HCl}$, $0.01 \mathrm{~g}$; vitamin solution, $1 \mathrm{ml}$. The composition of the vitamin solution was such that the concentration of the components in the medium was the same as the medium of Scott \& Dehority (1965). Either $0.5 \%$ glucose or $2 \%$ DL-lactate were added as the carbon/energy source. All media were adjusted to $\mathrm{pH} 6.8$ before being dispensed into $7.5 \mathrm{ml}$ aliquots in Hungate tubes, or $400 \mathrm{ml}$ aliquots in $1000 \mathrm{ml}$ Duran bottles (Gallenkamp) with crimp-top attachments, and autoclaved.

Growth of bacteria. Batch cultures were grown under $\mathrm{O}_{2}$-free $\mathrm{CO}_{2}$ in $7.5 \mathrm{ml}$ of medium in Hungate tubes from an inoculum of $0.2 \mathrm{ml}$ from an overnight culture. Cultures were incubated at $39{ }^{\circ} \mathrm{C}$ and the cell density was estimated by gently inverting the tubes before measuring optical density at $650 \mathrm{~nm}$ in a Bausch \& Lomb spectronic 20 spectrophotometer. Larger volume batch cultures were in $1000 \mathrm{ml}$ Duran bottles (Gallenkamp) with crimp-top attachments. Samples were removed aseptically by syringe and transferred to sterile, $\mathrm{CO}_{2}$-filled Hungate tubes for optical density measurements.

Fermentation analyses. Fermentation products were measured in the supernatant fluid from centrifuged culture samples by the capillary gas chromatography method of Richardson et al. (1989) using a 5890 series II gas chromatograph (Hewlett Packard).

To measure D-lactate and L-lactate separately in supernatant fluid, samples were first deproteinized by adding trichloroacetic acid (TCA) to a final concentration of $5 \%$ and leaving at $4{ }^{\circ} \mathrm{C}$ for $5 \mathrm{~min}$. The precipitate was removed by filtration before the samples were neutralized with potassium hydroxide. D-Lactate was then measured using the method described by Bergmeyer $\&$ Gahwehn (1974) using D-LDH from Leuconostoc mesenteroides (EC 1.1.1.28) and L-lactate was measured by the automated enzymatic procedure of Hochella \& Weinhouse (1965). Glucose was measured by the Lever assay (Lever, 1977).

Preparation of cell free extract. Cells were collected by centrifugation $\left(4^{\circ} \mathrm{C}, 3000 \mathrm{~g}, 20 \mathrm{~min}\right)$, washed once in $50 \mathrm{mM}$ sodium phosphate buffer ( $\mathrm{pH} 6 \cdot 8)$ and resuspended in the same buffer. All transfers of cell suspensions were carried out anaerobically. Cells were disrupted using an MSE Soniprep 150 at full power for $5 \mathrm{~min}$ with alternate $30 \mathrm{~s}$ on/off periods and keeping the samples on ice throughout. Cell debris was removed by centrifugation $\left(13400 \mathrm{~g}, 4^{\circ} \mathrm{C}, 1 \mathrm{~h}\right)$ and the supernatant was either used immediately or stored at $-70^{\circ} \mathrm{C}$ until required.

Zymograms. Approximately $20 \mu \mathrm{l}$ of sample was loaded onto a non-denaturing polyacrylamide gel containing a $2 \cdot 7 \%$ stacking gel and a $7.5 \%$ running gel. Electrophoresis was at $10 \mathrm{~mA}$ with $0.25 \mathrm{M}$ Tris/glycine $\mathrm{pH} 8.3$, with constant cooling using circulating cold water. Gels were stained until bands appeared by incubation at $37^{\circ} \mathrm{C}$ in the reaction mixture: $25 \mathrm{ml} 0.1 \mathrm{M}$ Tris $/ \mathrm{HCl} \mathrm{pH} 8.0,1.5 \mathrm{ml} 2 \mathrm{M} \mathrm{D}$ - or L-lactate, $72 \mathrm{mg} \mathrm{NAD}$, $3.6 \mathrm{mg}$ nitroblue tetrazolium and $2 \mathrm{mg}$ phenazine methosulphate (PMS). 
Enzyme assays. The nLDH activity in samples was assayed using pyruvate as the substrate as described by Wallace (1978) but at $\mathrm{pH} 6 \cdot 5$ : therefore the reaction mixture contained NADH, $0.3 \mathrm{mM}$; sodium pyruvate, $10 \mathrm{mM}$; potassium phosphate buffer, $50 \mathrm{miM}$ ( $\mathrm{pH} \mathrm{6.5);} \mathrm{and} \mathrm{sample.} \mathrm{The} \mathrm{reaction} \mathrm{was} \mathrm{performed} \mathrm{at}$ $25^{\circ} \mathrm{C}$ and the absorbance change at $340 \mathrm{~nm}$ measured. nLDH assays with lactate as the substrate were performed with 3acetylpy ridine adenine dinucleotide (APAD) as the cofactor and cofactor reduction measured at $365 \mathrm{~nm}$ as described by Wittenberger (1966): i.e. Tris $/ \mathrm{HCl}, 100 \mathrm{mM}$ (pH 8.0); lithium D- or L-lactate, $87.3 \mathrm{mM}$; APAD, $2 \mathrm{mM}$; and sample at $25^{\circ} \mathrm{C}$. Assays for $\mathrm{nLDH}$ were also carried out by the method of Scheifinger et al. (1975a) with the following reaction mixture: potassium phosphate buffer, $50 \mathrm{mM}(\mathrm{pH} 8.5)$; lithium D- or Llactate, $87.3 \mathrm{mM}$; NAD, $0.3 \mathrm{mM}$; and sample at $25^{\circ} \mathrm{C}$.

Assays for iLDH essentially followed the method described by Macy et al. (1978) but were performed at $\mathrm{pH} 6.5$ : i.e. potassium phosphate buffer, $50 \mathrm{mM}$ (pH 6.5); lithium D- or L-lactate, $5 \mathrm{mM}$; 2,6-dichlorophenol indophenol (DCPIP), $0 \cdot 15 \mathrm{mM}$; and sample at $30^{\circ} \mathrm{C}$ and measuring absorbance at $600 \mathrm{~nm}$. All absorbance measurements for assays were performed using a Cecil CF 595 double beam UV spectrophotometer with a path length of $1 \mathrm{~cm}$.

Lactate racemase activity was estimated using the procedure described by Dennis \& Kaplan (1963). Reaction mixtures contained $0 \cdot 1 \mathrm{M}$ sodium acetate $(\mathrm{pH} 5 \cdot 0), 0 \cdot 2 \mathrm{M}$ lithium $\mathrm{D}^{-}$or Llactate and cell extract in a final volume of $1 \mathrm{ml}$. The reaction was allowed to proceed at $37^{\circ} \mathrm{C}$ and at specific times aliquots were removed and boiled for $5 \mathrm{~min}$. Following cooling on ice, samples were centrifuged at $13400 \mathrm{~g}$ for $20 \mathrm{~min}$ at $4{ }^{\circ} \mathrm{C}$ and the supernatant withdrawn for analysis of $\mathrm{D}$ - and L-lactate.

For the purpose of specific activity calculations protein was measured in all samples by the Lowry method.

Separation of enzyme activities. Gel filtration was carried out at $4^{\circ} \mathrm{C}$, on a $2.5 \times 100 \mathrm{~cm}$ Ultrogel AcA 34 column (IBF Biotechnics) equilibrated with $50 \mathrm{mM}$ sodium phosphate, $\mathrm{pH} \mathrm{6.8.} \mathrm{The} \mathrm{column} \mathrm{was} \mathrm{calibrated} \mathrm{with} \mathrm{blue} \mathrm{dextran,} \mathrm{sweet}$ potato $\beta$-amylase $\left(M_{\mathrm{r}} 200000\right)$, yeast alcohol dehydrogenase $(150000)$, bovine serum albumin $(66000)$ and bovine erythrocyte carbonic anhydrase $(29000)$. Samples were run at a flow rate of $20 \mathrm{ml} \mathrm{h}^{-1}$ and $3 \mathrm{ml}$ fractions were collected for assaying purposes. Samples were also run on a Sephadex G-100 column of the same size with $50 \mathrm{mM}$ sodium phosphate buffer, $\mathrm{pH} 6.8$ at a flow rate of $14 \mathrm{ml} \mathrm{h}^{-1}$, collecting $5 \mathrm{ml}$ fractions. This column was calibrated with blue dextran, bovine serum albumin, bovine erythrocyte carbonic anhydrase, horse heart cytochrome $c$ $\left(M_{r} 12400\right)$ and bovine lung aprotinin (6500). Protein in the eluent was detected by measuring absorbance at $280 \mathrm{~nm}$ on an LKB 8300 Uvicord.

\section{RESULTS}

\section{Growth rates and fermentation}

The abilities of four lactate utilizing strains of $S$. ruminantium (5934e, HD4, 5521C1 and JW13) to metabolize lactate as the sole carbon and energy source were compared. Strain $5934 \mathrm{e}$ reached the highest maximum $\mathrm{OD}_{650}$ of $1 \cdot 2$, and exhibited the highest growth rate (generation time $2 \cdot 4 \mathrm{~h}$ ), and was therefore selected as the most appropriate strain for further study. This strain grown in batch culture on $\mathrm{D}$-medium $+0.5 \%$ glucose as the sole carbon/energy source initially produced mainly lactate with a low level of propionate and little or no acetate as fermentation end-products (Fig. 1a); succinate was not detected at significant levels. When all the glucose was utilized and the culture had entered stationary phase, accumulated lactate was converted to propionate and acetate, as shown previously with $S$. ruminantium strain HD4 (Scheifinger et al., 1975a; Melville et al., 1987) and strain B (Hishinuma et al., 1968). Strain 5934e showed no apparent preference for $\mathrm{D}$ - or L-lactate when grown on media with an equal concentration of the isomers as the sole carbon/energy source; after $15 \mathrm{~h}$ more than $90 \%$ of the lactate initially present in the medium had been taken up by the cells (Fig. 2). Also, both isomers of lactate were found to be produced from glucose (data not shown).

\section{Lactate dehydrogenase activities in strain 5934e}

Previous work on strain HD4 revealed one major $\mathrm{LDH}$ activity which was an L-nLDH (Scheifinger et al., 1975a; Melville et al., 1987). A single band of LDH activity was detected previously in S. ruminantium strain 5934 e by nondenaturing PAGE (Flint \& Bisset, 1990). In the present work zymograms were stained with L-lactate and D-lactate separately and activity was shown to be due to an $\mathrm{L}_{-}$ nLDH. The $\mathrm{L}-\mathrm{nLDH}$ band was found to be more intense with glucose-grown cell extracts than it was with lactategrown cell extracts (Fig. 3).
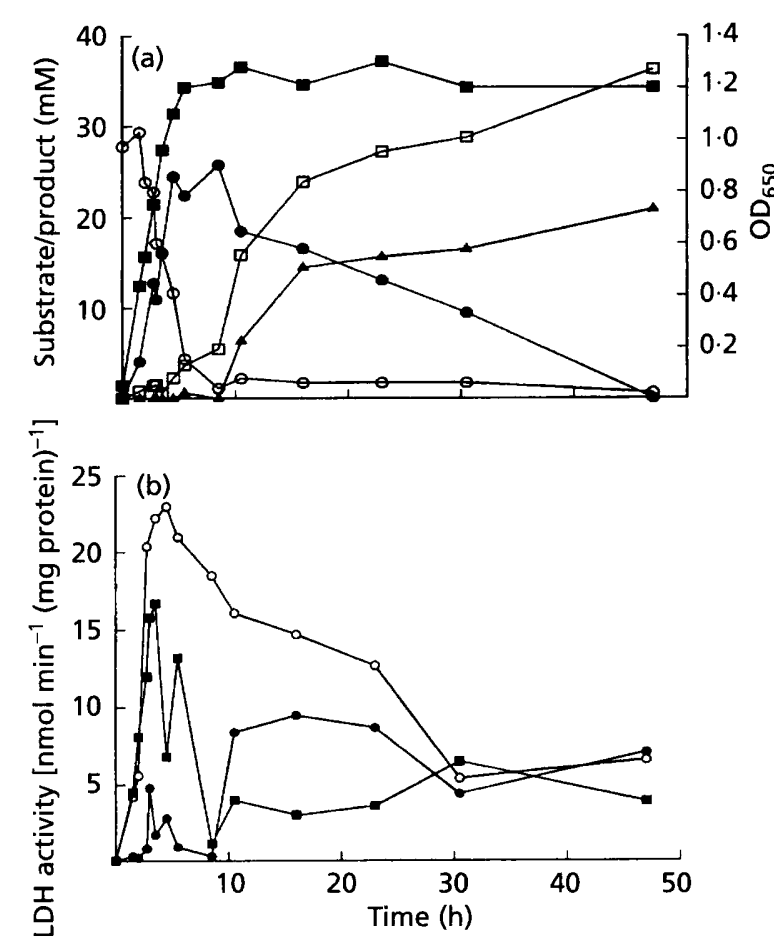

Fig. 1. (a) Growth and fermentation products of $S$. ruminantium strain $5934 \mathrm{e}$ grown on glucose in batch culture: 口. $\mathrm{OD}_{650} ; O$, glucose; $O$. DL-lactate; $\square$, propionate; $\boldsymbol{\Delta}_{\text {, }}$ acetate. (b) Lactate dehydrogenase activities in cell extracts of the same batch culture: O, D-iLDH; O, L-nLDH; $\mathbf{a}, \mathrm{D}-\mathrm{nLDH}$. Activity is expressed as nmol DCPIP reduced $\mathrm{min}^{-1}(\mathrm{mg}$ protein) $)^{-1}$ for iLDH and $\mathrm{nmol}$ APAD reduced $\mathrm{min}^{-1}$ (mg protein) $^{-1}$ for $n L D H$. 


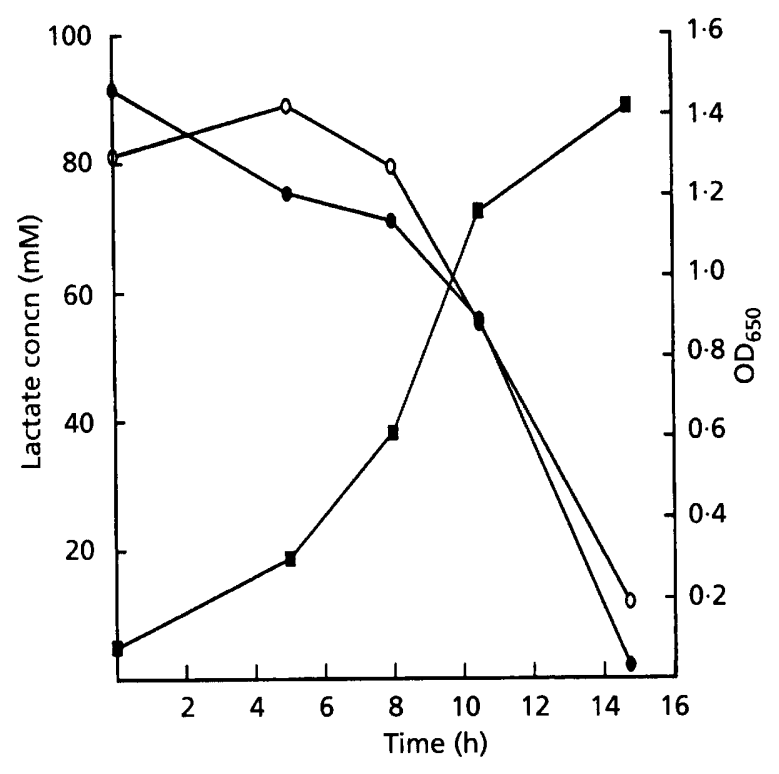

Fig. 2. Utilization of DL-lactate by S. ruminantium strain $5934 \mathrm{e}$ in batch culture. $\mathbf{0}, \mathrm{OD}_{650}$; $\mathrm{O}$, D-lactate; $\mathbf{O}$, L-lactate.

LDH assays were carried out using cells growing exponentially on basal $\mathrm{M} 2+$ glucose, which are utilizing glucose and producing lactate (Fig. 1a). NADH-dependent reduction of pyruvate was readily observed in cell free extracts; however, assays of reduction of $\mathrm{L}$ - or $\mathrm{D}$ lactate with NAD as cofactor gave low or undetectable activities (Table 1). These activities could be stimulated at least threefold by replacing NAD with the analogue APAD. This preference of some nLDH enzymes for APAD over NAD has been discussed by previous authors (Holzer \& Soling, 1962; Wittenberger, 1966) and appears to be a property of dehydrogenases related to the higher redox potential of APAD.

The assays were repeated with S. ruminantium strain $5934 \mathrm{e}$ cells grown to the mid-exponential phase on basal M2

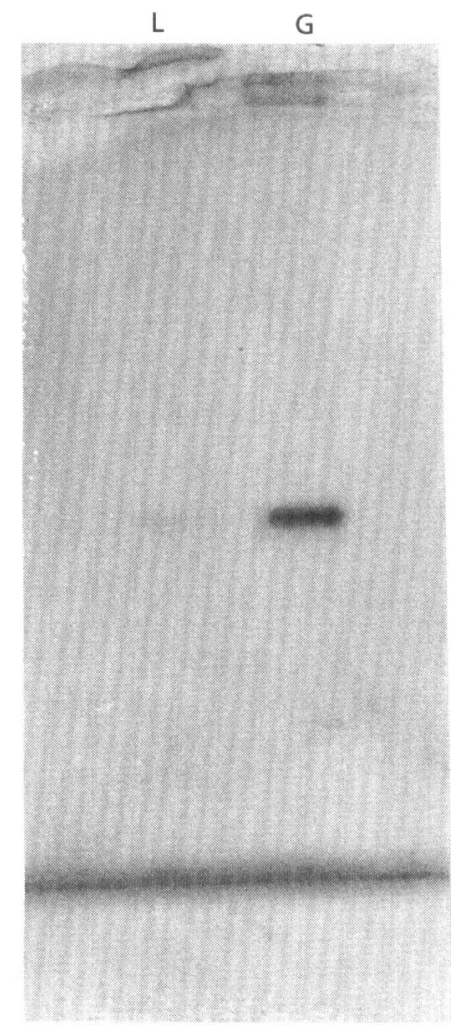

Fig. 3. Non-denaturing PAGE of S. ruminantium strain $5934 \mathrm{e}$ cell extract, stained for L-nLDH activity. L, Lactate-grown cells; G, glucose-grown cells.

medium + DL-lactate. In assays with pyruvate as the substrate the level of $\mathrm{LDH}$ activity was approximately 10 fold lower in extracts prepared from lactate-grown cells compared to glucose-grown cells, and lower activity was also found for the L-nLDH using L-lactate as substrate and APAD as the cofactor. The lower L-nLDH activity present in the lactate-grown cells could not be detected when NAD was used as the cofactor (Table 1). These

\section{Table 1. Lactate dehydrogenase activities in S. ruminantium strain $5934 \mathrm{e}$}

Values given are means of triplicate determinations, with calculated standard deviation. Extracts were prepared from cells grown to midexponential phase on basal M2+ glucose or + DL-lactate.

\begin{tabular}{|c|c|c|c|c|c|c|}
\hline \multirow[t]{3}{*}{ Extract } & \multicolumn{6}{|c|}{ LDH activity* } \\
\hline & \multirow{2}{*}{$\frac{\mathrm{Pyr} \rightarrow \mathrm{Lac}}{\mathrm{NADH}^{\mathrm{a}}}$} & \multicolumn{2}{|c|}{ L-Lac $\rightarrow$ Pyr } & \multicolumn{3}{|c|}{ D-Lac $\rightarrow$ Pyr } \\
\hline & & $\mathbf{A P A D}^{\mathbf{b}}$ & NAD $^{c}$ & $\mathbf{A P A D}^{\mathrm{b}}$ & $\mathbf{N A D}^{\mathrm{c}}$ & DCPIP \\
\hline Glucose & $2424 \pm 897$ & $13 \cdot 2 \pm 1 \cdot 9$ & $<5$ & $14 \cdot 4 \pm 5 \cdot 0$ & ND & $<2$ \\
\hline DL-Lactate & $284 \pm 156$ & $<5$ & ND & $16 \cdot 4 \pm 3.5$ & ND & $22 \cdot 5 \pm 11 \cdot 1$ \\
\hline
\end{tabular}

* Activity is expressed as (a) nmol NADH oxidized $\min ^{-1}(\mathrm{mg} \text { protein })^{-1} ;(\mathrm{b})$, nmol APAD reduced $\mathrm{min}^{-1}\left(\mathrm{mg} \mathrm{protein}^{-1}\right.$; (c), nmol NAD reduced $\min ^{-1}$ ( $\mathrm{mg}$ protein $)^{-1} ;(\mathrm{d})$, nmol DCPIP reduced $\min ^{-1}$ (mg protein $)^{-1}$.

$\mathrm{ND}$, Not detectable $\left.\left[<0.4 \mathrm{nmol} \text { substrate reduced or oxidized } \mathrm{m}^{-1} \text { (mg protein }\right)^{-1}\right]$. 
measurements are consistent with the results of the LDH zymograms (Fig. 3) showing greater L-nLDH activity in glucose extracts. D-Lactate specific nLDH activity was similar in extracts of lactate-grown cells and glucosegrown cells, but was only detectable when APAD was used as cofactor (Table 1). The relative differences in the two nLDH activities between glucose-grown cells and lactate-grown cells suggested that $S$. ruminantium strain 5934e may possess two distinct nLDH enzymes. Although lactate racemase activity was detected in crude extracts, it was similar in cells grown on either glucose or lactate (data not shown), and therefore could not explain the observed differences in lactate oxidation.

In lactate-grown cells a significant NAD-independent $\mathrm{D}-$ $\mathrm{LDH}$ (D-iLDH) activity was detected, which was approximately 10-fold higher than in glucose-grown cells (Table 1). This activity was apparently induced when $S$. ruminantium cells were utilizing lactate and suggested the existence of a third LDH distinct from the nLDH activities already identified. Unlike the L-iLDH activity previously detected in strain HD4 (Scheifinger et al., 1975a), addition of NAD or PMS to D-iLDH assay mixtures did not increase the activity. Only trace levels of L-iLDH activity $\left[<0.5 \mathrm{nmol}\right.$ DCPIP reduced $\mathrm{min}^{-1}(\mathrm{mg}$ protein $)^{-1}$ ] could be detected in any cell extracts of strain 5943e.

\section{Separation of LDH activities from strain 5934e}

In order to demonstrate that the three LDH activities in $S$. ruminantium strain $5934 \mathrm{e}$ were due to different enzymes, a cell extract prepared from mid-exponential cells grown on D-medium $+2 \%$ DL-lactate was fractionated by gel filtration on Ultrogel AcA 34. The elution profile from the gel filtration column showed three distinct activity peaks (Fig. 4). The D-iLDH peak corresponded to a protein with an approximate $M_{\mathrm{r}}$ of 280000 and the fractions making up this peak contained no D-nLDH activity. An approximate $M_{\mathrm{r}}$ of 140000 was found for the L-nLDH and this was in agreement with the $M_{\mathrm{r}}$ of 150000 estimated from non-denaturing PAGE (results not shown). The third enzyme, the D-nLDH, was separated from the other two LDH activities but this enzyme was eluted from the column at the same elution volume as $\mathrm{NaCl}$ suggesting an $M_{\mathrm{r}}$ less than the lower exclusion limit of the gel matrix, i.e. $<20000$. A small peak of $\mathrm{D}-\mathrm{nLDH}$ activity was also detected in the fractions containing $\mathrm{L}-\mathrm{nLDH}$, perhaps due to non-specificity of the L-nLDH. Sephadex G-100 gel filtration chromatography of a sample prepared in the same way indicated that the D-nLDH had an $M_{\mathrm{r}}$ of approximately 10000 .

The recoveries of the three $\mathrm{LDH}$ activities from gel filtration were low $(11 \%, 28 \%$ and $1 \%$ for $\mathrm{L}-\mathrm{nLDH}$, D$\mathrm{nLDH}$ and $\mathrm{D}$-iLDH respectively). These recoveries correlated with stability of the activities after storage at $4{ }^{\circ} \mathrm{C}$ for $48 \mathrm{~h}(37 \%, 76 \%$ and $10 \% \mathrm{~L}$-nLDH, D-nLDH and $\mathrm{D}-\mathrm{iLDH}$ activity retained respectively). Addition of the protease inhibitors EDTA $(1 \mathrm{mM})$ or PMSF $\left(100 \mu \mathrm{g} \mathrm{ml}^{-1}\right)$ to samples of crude extract did not increase the stability of LDH activities on incubation at various

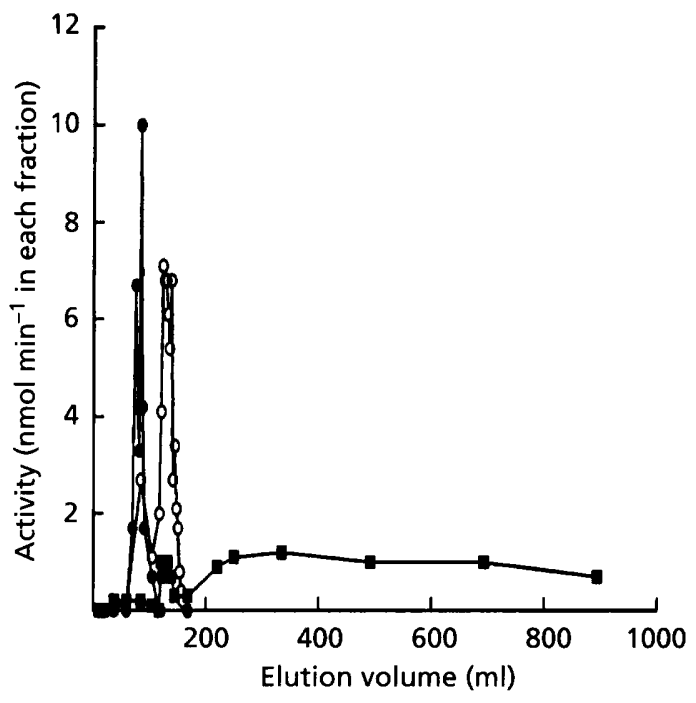

Fig. 4. Elution profile of the three lactate dehydrogenase activities of $S$. ruminantium strain 5934e, DL-lactate-grown, cell extract, after gel filtration on Ultrogel ACA 34. O, D-iLDH; O, L$\mathrm{nLDH} ; \mathbf{D}, \mathrm{D}-\mathrm{nLDH}$. Activity is expressed as nmol DCPIP reduced $\mathrm{min}^{-1}$ by each fraction for iLDH and $\mathrm{nmol}$ APAD reduced $\mathrm{min}^{-1}$ by each fraction for $n L D H$.

temperatures from $4{ }^{\circ} \mathrm{C}$ to $37^{\circ} \mathrm{C}$, and the presence of $0.5 \mathrm{mM}$ dithiothreitol during gel filtration did not significantly increase the recovery of the enzyme activities (data not shown). Due to the low recoveries of activity, no further purification was attempted.

The preference of the semi-purified nLDHs for APAD over NAD as the cofactor was the same as for the corresponding activities in crude extracts (results not shown). The rate of pyruvate reduction by the $\mathrm{L}$-nLDH was again approximately 200 -fold greater than that of $\mathrm{L}^{-}$ lactate oxidation. No activity could be measured with the D-nLDH fraction using pyruvate as the substrate with either NADH or APADH as cofactor indicating that all the pyruvate to lactate activity in crude extracts is due to the $\mathrm{L}-\mathrm{nLDH}$. This was confirmed by the direct demonstration that only L-lactate was produced during pyruvate oxidation (data not shown).

Approximate $K_{\mathrm{m}}$ values with respect to the relevant isomer of lactate for the semi-purified L-nLDH, D-nLDH and D-iLDH enzymes were estimated at $45 \mathrm{mM}, 70 \mathrm{mM}$ and $0.5 \mathrm{mM}$ respectively; therefore the D-iLDH has the highest affinity for lactate. The $K_{\mathrm{m}}$ value of the L-nLDH for pyruvate was $0.5 \mathrm{mM}$, which is considerably lower than the $K_{\mathrm{m}}$ for L-lactate.

\section{LDH activities in strain 5934e at different growth phases}

Cell extracts of $S$. ruminantium 5934e obtained from different stages of growth on glucose were assayed for all three $\mathrm{LDH}$ activities (Fig. 1b). Both nLDH activities peaked during exponential growth, when glucose was being converted to lactate, although activity could be 
Table 2. Lactate dehydrogenase activities in extracts of different strains of $S$. ruminantium grown on glucose or DL-lactate

Values given are means from two determinations. Extracts were prepared from cells grown to midexponential phase on basal M2 $+0.5 \%$ glucose (Glc) or on basal M2 $+2 \%$ DL-lactate (Lac).

\begin{tabular}{|c|c|c|c|c|c|c|c|c|}
\hline \multirow[t]{3}{*}{ Strain } & \multicolumn{8}{|c|}{ LDH activity* } \\
\hline & \multicolumn{2}{|c|}{ L-nLDH ${ }^{a}$} & \multicolumn{2}{|c|}{ D-nLDH ${ }^{a}$} & \multicolumn{2}{|c|}{ D-iLDH ${ }^{b}$} & \multicolumn{2}{|c|}{$\mathbf{L}-\mathbf{i L D H}{ }^{\mathrm{b}}$} \\
\hline & Glc & Lac & Glc & Lac & Glc: & Lac & Glc & Lac \\
\hline $5934 \mathrm{e}$ & $28 \cdot 0$ & $9 \cdot 2$ & $14 \cdot 7$ & $13 \cdot 5$ & $0 \cdot 7$ & $15 \cdot 5$ & ND & ND \\
\hline HD4 & $16 \cdot 3$ & $10 \cdot 9$ & $6 \cdot 1$ & $25 \cdot 7$ & $0 \cdot 3$ & $32 \cdot 1$ & ND & $3 \cdot 8$ \\
\hline $5521 \mathrm{C} 1$ & $25 \cdot 9$ & $2 \cdot 1$ & $13 \cdot 9$ & $22 \cdot 9$ & $0 \cdot 4$ & $6 \cdot 2$ & ND & ND \\
\hline JW13 & $23 \cdot 0$ & $2 \cdot 0$ & $15 \cdot 4$ & $9 \cdot 0$ & $0 \cdot 5$ & $14 \cdot 1$ & ND & ND \\
\hline FB322 & $17 \cdot 2$ & - & $10 \cdot 3$ & - & $\mathrm{ND}$ & - & ND & - \\
\hline GA 192 & $16 \cdot 1$ & - & 4.9 & - & ND & - & ND & - \\
\hline $\mathrm{D}$ & $42 \cdot 9$ & - & $15 \cdot 3$ & - & ND & - & ND & - \\
\hline
\end{tabular}

* Activity is expressed as (a) nmol APAD reduced $\min ^{-1}$ (mg protein $)^{-1}$; (b) nmol DCPIP reduced $\min ^{-1}$ $(\mathrm{mg} \text { protein })^{-1}$.

ND, Not detectable $\left[<0.4 \mathrm{nmol}\right.$ substrate reduced or oxidized $\left.\min ^{-1}(\text { mg protein })^{-1}\right]$.

detected throughout the stationary phase of growth. The $\mathrm{D}$-iLDH activity, on the other hand, was present at very low levels during the exponential phase, but was markedly stimulated in stationary phase cells which were actively utilizing lactate (Fig. 1).

\section{LDH activities in other strains of S. ruminantium}

Three other lactate utilizing strains of S. ruminantium were tested for $\mathrm{nLDH}$ and iLDH activities by assaying extracts of both glucose-grown and lactate-grown cells. LDH activities in strains 5521C1, JW13 and HD4 followed a similar pattern to strain $5934 \mathrm{e}$ (Table 2) except that strain HD4 exhibited low levels of L-iLDH activity when grown with DL-lactate as the sole energy source. This may be the same L-iLDH activity found previously at low levels in strain HD4 (Scheifinger et al., 1975a ; Melville et al., 1987) or could be due to a highly active lactate racemase in strain HD4 converting L-lactate in the assay to D-lactate.

Three lactate non-utilizing strains of $S$. ruminantium, FB322, GA192 and D, were grown on glucose and cell extracts examined for $\mathrm{nLDH}$ and iLDH activities. The activities found were similar to those in lactate utilizing strains grown on glucose, and the iLDH activities were absent or insignificant (Table 2).

\section{DISCUSSION}

This work shows for the first time that multiple LDHs are present in strains of Selenomonas ruminantium. The DiLDH of strain $5934 \mathrm{e}$ was only detected at significant levels in cells grown with lactate as the sole carbon and energy source (Table 1) and the enzyme had a higher affinity for lactate than the cofactor dependent LDH activities, suggesting that it is the enzyme most likely to be involved in lactate utilization in vivo. In $S$. ruminantium strain HD4, Joyner \& Baldwin (1966) found low levels of both D-iLDH and L-iLDH, while Wallace (1978) found low levels of iLDH in strain WPL 151/1, but in both these studies cells were grown only on glucose. Therefore this is the first report of a $\mathrm{LDH}$ activity induced by lactate in S. ruminantium.

Strain 5934e was found to utilize L-lactate and D-lactate at approximately the same rate when grown on DL-lactate (Fig. 2), presumably due to the presence of lactate racemase, which was detected in extracts of cells grown on either glucose or lactate. The ability to use both $\mathrm{D}$ - and L-lactate may enhance the survival of $S$. ruminantium within the rumen where $\mathrm{D}$ - and L-lactate are both present. However, the fact that only D-iLDH activity and no LiLDH activity was detected in extracts of 5934e and two other strains indicates that the racemase does not contribute to the in vitro $\mathrm{LDH}$ assays under the conditions used.

D-iLDH activity, which was found in all lactate utilizers, was particularly unstable. Overnight dialysis of cell extract of lactate-grown strain 5934e resulted in the loss of over $90 \%$ of the D-iLDH activity (results not shown), which may explain why it was not detected in previous studies examining lactate-grown cells and cells grown at different dilution rates on glucose (Scheifinger et al., 1975a; Melville et al., 1987). Further purification and characterization of the enzyme will depend on a means of overcoming the problem of the rapid loss of activity after cell disruption.

The normal electron acceptor for the D-iLDH in vivo is not known in S. ruminantium but it is tempting to speculate that this may involve the anaerobic respiratory chain. $S$. ruminantium strains WPL 151/1, 6, 21 and GFA are known 
to contain a membrane associated cytochrome $b$ which in its reduced form is oxidizable by fumarate (De Vries $e t a l$., 1974; Henderson, 1980), and it is possible that lactate oxidation could be linked to fumarate reduction in vivo.

The $\mathrm{L}$-nLDH detected in strain 5934e appears to be similar to the enzyme previously described in strain HD4 (Scheifinger et al., 1975a; Melville et al., 1987, 1988a), having a similar $M_{\mathrm{r}}$. The higher levels of $\mathrm{L}-\mathrm{nLDH}$ activity found in glucose-grown cells compared with lactate-grown cells (Table 1, Fig. 3) and the much lower (90-fold) $K_{\mathrm{m}}$ value for pyruvate than for lactate suggest that this enzyme is more important in glucose metabolism than in lactate metabolism. Assays with L-lactate as the substrate were more sensitive when APAD was used instead of NAD as the cofactor (Table 1) due to the greater electron accepting power of APAD (Kaplan \& Ciotti, 1956).

The third activity detected in all four lactate utilizing strains, D-nLDH, was only measurable in a quantitative manner when APAD and D-lactate were used as cofactor and substrate in the assays (Table 1). However, in colorimetric assays containing D-lactate, NAD, nitroblue tetrazolium and PMS activity was detected in crude extracts (results not shown) suggesting that under some conditions NAD/NADH can be used as a cofactor by this enzyme. The role of this enzyme in vivo is as yet unclear. It had a relatively high $K_{\mathrm{m}}$ value for D-lactate but a method of assaving the enzyme in the pyruvate to lactate direction is needed to estimate the $K_{\mathrm{m}}$ value for pyruvate. The small size of this $\mathrm{D}-\mathrm{nLDH}$ is unusual compared to other bacterial D-nLDH enzymes which have $M_{\mathrm{r}}$ values of 70000-80000 or larger (Garvie, 1980), although it is possible that the DnLDH activity measured after gel filtration results from denaturation of the enzyme into individual subunits. The only other report of a D-nLDH activity in S. ruminantium was that of Wallace (1978) in strain WPL 151/1. However, this activity was assayed using pyruvate as the substrate and $\mathrm{NADH}$ as the cofactor and therefore may be of a different type from the enzyme in strain 5934e.

It has been estimated that the major contribution $(60-80 \%)$ to lactate fermentation in the rumen is made by $M$. elsdenii via the 'acrylate' pathway, and a lower contribution is made by organisms such as $S$. ruminantium that employ the alternative 'randomizing' pathway for propionate formation from lactate (Counotte et al., 1981). One of the main reasons for the relatively low contribution of $S$. ruminantium is likely to be repression of lactate utilization in the presence of readily utilizable sugars, which is not observed in M. elsdenii. In addition, many S. ruminantium strains are not lactate utilizers, and we also found that there is considerable variation between lactate utilizing strains in their growth responses with lactate as substrate. There may be scope for using specially selected strains of $S$. ruminantium such as 5934e, that show high lactate utilizing ability, to enhance lactate utilization in the rumen, but only if such strains could be modified so as to abolish the repression of lactate utilization by sugars. Now that the likely route for lactate assimilation in $S$. ruminantium has been established, further investigations can be expected to elucidate the regulation of lactate utilization in this organism.

\section{ACKNOWLEDGEMENTS}

This work was supported by an SERC-CASE award to M.G., with additional support from SOAFD (Scottish Office Agriculture and Fisheries Department). We are grateful to Dr R. J. Wallace for valuable discussions and advice.

\section{REFERENCES}

Baldwin, R. L., Wood, W. A. \& Emery, R. S. (1965). Lactate metabolism by Peptostreptococcus elsdenii: evidence for lactyl coenzyme A dehydrase. Biochim Biopbys Acta 97, 202-213.

Bergmeyer, H. U. \& Gahwehn, K. (1974). D-Lactate. In Methods of Enzymatic Analysis, 2nd edn, vol. 3, pp. 1492-1495. Edited by H. U. Bergmeyer. New York: Academic Press.

Brockman, H. L. \& Wood, W. A. (1975). D-Lactate dehydrogenase of Peptostreptococcus elsdenii. J Bacteriol 124, 1454-1461.

Bryant, M. P. (1956). 'The characteristics of strains of Selenomonas isolated from bovine rumen contents. $J$ Bacteriol 72, 162-167.

Bryant, M. P. (1972). Commentary on the Hungate technique for culture of anaerobic bacteria. Am J Clin Nutr 25, 1324-1328.

Bryant, M. P. (1984). Selenomonas. In Bergey's Manual of Systematic Bacteriology, vol. 1, pp. 650-653. Edited by N. R. Krieg \& J. G. Holt. Baltimore: Williams \& Wilkins.

Caldwell, D. R. \& Bryant, M. P. (1966). Medium without rumen fluid for nonselective enumeration and isolation of rumen bacteria. Appl Microbiol 14, 794-801.

Clark, B. \& Holms, W. H. (1976). Control of the sequential utilization of glucose and fructose by Escherichia coli.J Gen Microbiol 95, 191-201.

Counotte, G. H. M., De Groot, M. \& Prins, R. A. (1980). Kinetic parameters of lactate dehydrogenases of some rumen bacterial species, the anaerobic ciliate Isotricha prostoma and mixed rumen microorganisms. Antonie Leeuwenboek 46, 363-381.

Counotte, G. H. M., Prins, R. A., Janssen, R. H. A. M. \& Debie, M. J. A. (1981). Role of Megasphaera elsdenii in the fermentation of $\mathrm{DL}<\left[2{ }^{13} \mathrm{C}\right]$ lactate in the rumen of dairy cattle. Appl Environ Microbiol $42,649-655$.

Dennis, D. \& Kaplan, N. O. (1963). Lactic acid racemization in Clostridium butylicum. Biochem Z 338, 485-495.

De Vries, W., Van Wijck-Kapteyn, W. M. C. \& Oosterhuis, S. K. H. (1974). The presence and function of cytochromes in Selenomonas ruminantium, Anaerovibrio lipolytica and I eillonella alcalescens. J Gen Microbiol 81, 69-78.

Flint, H. J. \& Bisset, J. (1990). Genetic diversity in Selenomonas ruminantium isolated from the rumen. FEMS Microbiol Eicol 73, 351-360.

Flint, H. J., Duncan, S. H., Bisset, J. \& Stewart, C. S. (1988). The isolation of tetracycline resistant strains of strictly anaerobic bacteria from the rumen. Lett Appl Microbiol 6, 113-115.

Garvie, E. I. (1980). Bacterial lactate dehydrogenases. Microbiol Rev 44, 106-139.

Henderson, C. (1980). The influence of extracellular hydrogen on the metabolism of Bacteroides ruminicola, Anaerovibrio lipolytica and Selenomonas ruminantium. J Gen Microbiol 119, 485-491.

Hino, T. \& Kuroda, S. (1993). Presence of lactate dehydrogenase and lactate racemase in Megasphaera elsdenii grown on glucose or lactate. Appl Environ Microbiol 59, 255-259. 
Hishinuma, F., Kanegasaki, S. \& Takahashi, H. (1968). Ruminal fermentation and sugar concentration: a model experiment with Selenomonas ruminantium. Agric Biol Chem 32, 1325-1330.

Hobson, P. N. (1969). Rumen bacteria. Methods Microbiol 3B, 133-139.

Hochella, N. J. \& Weinhouse, S. (1965). Automated lactic acid determination in serum and tissue extracts. Anal Biochem 10, 304-317.

Holzer, H. \& Soling, H. D. (1962). Bestimmung von L-lactat, Lmalat, L-glutamat und athylalkohol im enzymatisch-optischen test mit hilfe des DPN-analogen 3-acetylpyridin-DPN. Biochem $Z$ 336, 201-214.

Hungate, R. E. (1966). The Rumen and its Microbes. New York: Academic Press.

John, A., Isaacson, H. R. \& Bryant, M. P. (1974). Isolation and characterisation of a ureolytic strain of Selenomonas ruminantium. $J$ Dairy Sci 57, 1003-1014.

Johns, A. T. (1951). The mechanism of propionic acid formation by I eillonella gazogenes. J Gen Microbiol 5, 326-336.

Joyner, A. E. \& Baldwin, R. L. (1966). Enzymatic studies of pure cultures of rumen microorganisms. J Bacteriol 92, 1321-1330.

Kaplan, N. O. \& Ciotti, M. M. (1956). Chemistry and properties of the 3 -acetylpyridine analogue of diphosphopyridine nucleotide. $J$ Biol Chem 221, 823-832.

Kemp, M. B. (1972). D- and L-lactate dehydrogenases of Pseudomonas aeruginosa. Biochem J 130, 307-309.

Kohn, L. D. \& Kaback, H. R. (1973). Mechanisms of active transport in isolated bacterial membrane vesicles. XV. Purification and properties of the membrane-bound $\mathbf{D}$-lactate dehydrogenase from Escherichia coli. J Biol Cbem 248, 7012-7017.

Lever, M. (1977). Carbohydrate determination with 4hydroxybenzoic acid hydrazide (PAHBAH): effect of bismuth on the reaction. Anal Biochem 81, 21-27.

Macy, J. M., Ljungdahl, L. G. \& Gottschalk, G. (1978). Pathway of succinate and propionate formation in Bacteroides fragilis. $J$ Bacteriol 134, 84-91.

Melville, S. B., Michel, T. A. \& Macy, J. M. (1987). Involvement of D-lactate and lactic acid racemase in the metabolism of glucose by Selenomonas ruminantium. FEMS Microbiol Lett 40, 289-293.
Melville, S. B., Michel, T. A. \& Macy, J. M. (1988a). Pathway and sites for energy conservation in the metabolism of glucose by Selenomonas ruminantium. J Bacteriol 170, 5298-5304.

Melville, S. B., Michel, T. A. \& Macy, J. M. (1988b). Regulation of carbon flow in Selenomonas ruminantium grown in glucose-limited continuous culture. J Bacteriol 170, 5305-5311.

Molinari, R. \& Lara, F. J. S. (1960). The lactic dehydrogenase of Propionibacterium pentosaceum. Biochem J 75, 57-65.

Paynter, M. J. \& Elsden, S. R. (1970). Mechanism of propionate formation by Selenomonas ruminantium, a rumen micro-organism. $J$ Gen Microbiol 61, 1-7.

Richardson, A. J., Calder, A. G., Stewart, C. S. \& Smith, A. (1989). Simultaneous determination of volatile and non-volatile acidic fermentation products of anaerobes by capillary gas chromatography. Lett Appl Microbiol 9, 5-8.

Scheifinger, C. C., Latham, M. J. \& Wolin, M. J. (1975a). Relationships of lactate dehydrogenase specificity and growth rate to lactate metabolism by Selenomonas ruminantium. Appl Microbiol 30 , 916-921.

Scheifinger, C. C., Linehan, B. \& Wolin, M. J. (1975b). $\mathrm{H}_{2}$ production by Selenomonas ruminantium in the absence and presence of methanogenic bacteria. Appl Microbiol 29, 480- 483.

Scott, H. W. \& Dehority, B. A. (1965). Vitamin requirements of several cellulolytic rumen bacteria. J Bacterio/ 89, 1169-1175.

Wallace, R. J. (1978). Control of lactate production by Selenomonas ruminantium: homotropic activation of lactate dehydrogenase by pyruvate. J Gen Microbiol 107, 45-52.

Wallace, R. J. \& Brammall, M. J. (1985). The role of different species of bacteria in the hydrolysis of protein in the rumen. $J$ Gen Microbiol 131, 821-832.

Wittenberger, C. L. (1966). Unusual kinetic properties of a DPNlinked lactate dehydrogenase from Butyribacterium rettgeri. Biochem Biophys Res Commun 22, 729-736.

Wittenberger, C. L. \& Haaf, A. S. (1966). Isolation of NADindependent lactate dehydrogenase from extracts of Butyribacterium rettgeri. Biochim Biophys Acta 122, 393-405.

Received 21 March 1994; accepted 27 April 1994. 